\title{
Front Matter: Volume 8638
}

, "Front Matter: Volume 8638," Proc. SPIE 8638, Laser Refrigeration of Solids VI, 863801 (21 March 2013); doi: 10.1117/12.2022483

SPIE. Event: SPIE OPTO, 2013, San Francisco, California, United States 


\section{PROCEEDINGS OF SPIE}

\section{Laser Refrigeration of Solids VI}

Richard I. Epstein

Denis V. Seletskiy

Mansoor Sheik-Bahae

Editors

6-7 February 2013

San Francisco, California, United States

Sponsored and Published by

SPIE 
The papers included in this volume were part of the technical conference cited on the cover and title page. Papers were selected and subject to review by the editors and conference program committee. Some conference presentations may not be available for publication. The papers published in these proceedings reflect the work and thoughts of the authors and are published herein as submitted. The publisher is not responsible for the validity of the information or for any outcomes resulting from reliance thereon.

Please use the following format to cite material from this book:

Author(s), "Title of Paper," in Laser Refrigeration of Solids VI, edited by Richard I. Epstein, Denis V. Seletskiy, Mansoor Sheik-Bahae, Proceedings of SPIE Vol. 8638 (SPIE, Bellingham, WA, 2013) Article CID Number.

ISSN: 0277-786X

ISBN: 9780819494078

Published by

SPIE

P.O. Box 10, Bellingham, Washington 98227-0010 USA

Telephone +1 3606763290 (Pacific Time) · Fax +1 3606471445

SPIE.org

Copyright (C) 2013, Society of Photo-Optical Instrumentation Engineers.

Copying of material in this book for internal or personal use, or for the internal or personal use of specific clients, beyond the fair use provisions granted by the U.S. Copyright Law is authorized by SPIE subject to payment of copying fees. The Transactional Reporting Service base fee for this volume is $\$ 18.00$ per article (or portion thereof), which should be paid directly to the Copyright Clearance Center (CCC), 222 Rosewood Drive, Danvers, MA 01923. Payment may also be made electronically through CCC Online at copyright.com. Other copying for republication, resale, advertising or promotion, or any form of systematic or multiple reproduction of any material in this book is prohibited except with permission in writing from the publisher. The CCC fee code is 0277-786X/13/\$18.00.

Printed in the United States of America.

Publication of record for individual papers is online in the SPIE Digital Library.

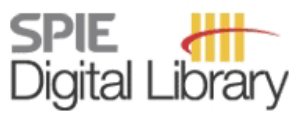

SPIEDigitalLibrary.org

Paper Numbering: Proceedings of SPIE follow an e-First publication model, with papers published first online and then in print and on CD-ROM. Papers are published as they are submitted and meet publication criteria. A unique, consistent, permanent citation identifier (CID) number is assigned to each article at the time of the first publication. Utilization of CIDs allows articles to be fully citable as soon as they are published online, and connects the same identifier to all online, print, and electronic versions of the publication. SPIE uses a six-digit CID article numbering system in which:

- The first four digits correspond to the SPIE volume number.

- The last two digits indicate publication order within the volume using a Base 36 numbering

system employing both numerals and letters. These two-number sets start with 00, 01, 02, 03, 04, $05,06,07,08,09,0 A, 0 B \ldots$. 0Z, followed by 10-1Z, 20-2Z, etc.

The CID Number appears on each page of the manuscript. The complete citation is used on the first page, and an abbreviated version on subsequent pages. Numbers in the index correspond to the last two digits of the six-digit CID Number. 


\title{
Contents
}

\author{
$\checkmark \quad$ Conference Committee \\ vii Group IV photonics for the mid infrared (Plenary Paper) [8629-1] \\ R. Soref, The Univ. of Massachusetts at Boston (United States) \\ xxii Light in a twist: optical angular momentum (Plenary Paper) [8637-2] \\ M. J. Padgett, Univ. of Glasgow (United Kingdom)
}

\section{SESSION 1 LASER REFRIGERATION IN RARE-EARTH DOPED SYSTEMS}

863803 Non-radiative decay of holmium-doped laser materials (Invited Paper) [8638-2]

S. R. Bowman, S. O'Connor, N. J. Condon, E. J. Friebele, W. Kim, B. Shaw, U.S. Naval

Research Lab. (United States); R. S. Quimby, Worcester Polytechnic Institute (United States)

863804 Optical refrigeration progress: cooling below NIST cryogenic temperature of 123K (Invited Paper) [8638-3]

S. D. Melgaard, The Univ. of New Mexico (United States); D. V. Seletskiy, The Univ. of New Mexico (United States), Air Force Research Lab. (United States), and Univ. Konstanz (Germany); A. Di Lieto, M. Tonelli, Univ. di Pisa (Italy); M. Sheik-Bahae, The Univ. of New Mexico (United States)

863805 Progress towards cryogenic temperatures in intra-cavity optical refrigeration using a VECSEL [8638-4]

A. R. Albrecht, M. Ghasemkhani, The Univ. of New Mexico (United States); J. G. Cederberg, Sandia National Labs. (United States); D. V. Seletskiy, Univ. Konstanz (Germany);

S. D. Melgaard, M. Sheik-Bahae, The Univ. of New Mexico (United States)

863806 Laser cooling with rare-earth doped direct band gap semiconductors (Invited Paper) [8638-5]

G. Nemova, R. Kashyap, Ecole Polytechnique de Montréal (Canada)

SESSION 2 LASER REFRIGERATION IN SEMICONDUCTOR SYSTEMS

$863807 \quad$ Electro-luminescent cooling: light emitting diodes above unity efficiency (Invited Paper) [8638-6]

P. Santhanam, D. Huang, Massachusetts Institute of Technology (United States);

D. J. Gray Jr., Massachusetts Institute of Technology (United States) and Stanford Univ. (United States); R. J. Ram, Massachusetts Institute of Technology (United States)

863808 Laser cooling of a semiconductor by $\mathbf{4 0}$ kelvin: an optical refrigerator based on cadmium sulfide nanoribbions (Invited Paper) [8638-7]

J. Zhang, D. Li, R. Chen, Q. Xiong, Nanyang Technological Univ. (Singapore) 
SESSION $3 \quad$ NOVEL APPROACHES IN LASER COOLING

8638 OC Towards redistribution laser cooling of molecular gases: production of candidtate molecules SrH by laser ablation (Invited Paper) [8638-11]

P. Simon, P. Moroshkin, L. Weller, A. Saß, M. Weitz, Rheinische Friedrich-Wilhelms-Univ. Bonn (Germany)

8638 OD Electrocaloric refrigerator using electrohydrodynamic flows in dielectric fluids (Invited Paper) [8638-12]

M. P. Hehlen, A. H. Mueller, N. R. Weisse-Bernstein, Los Alamos National Lab. (United States);

R. I. Epstein, ThermoDynamic Films, LLC (United States)

SESSION 4 ADVANCES IN SOLID-STATE LASER REFRIGERATION

8638 OG Towards all-fiber optical coolers using Tm-doped glass fibers (Invited Paper) [8638-15]

D. T. Nguyen, R. Thapa, D. Rhonehouse, J. Zong, A. Miller, NP Photonics, Inc. (United States); G. Hardesty, The Univ. of Arizona (United States); N. H. Kwong, College of Optical Sciences, The Univ. of Arizona (United States); R. Binder, The Univ. of Arizona (United States) and College of Optical Sciences, The Univ. of Arizona (United States); A. Chavez-Pirson, NP Photonics, Inc. (United States)

$8638 \mathrm{OH}$ Accurate measurement of external quantum efficiency in semiconductors (Invited Paper) [8638-16]

C. Wang, M. Sheik-Bahae, The Univ. of New Mexico (United States); J. Cederberg,

D. Bender, Sandia National Labs. (United States)

$8638 \mathrm{Ol} \quad$ Spectroscopic and life-time measurements of quantum dot doped glass for optical refrigeration: a feasibility study [8638-17]

S. Loranger, A. Lesage-Landry, E. Soares de Lima Filho, G. Nemova, Ecole Polytechnique de Montréal (Canada); N. O. Dantas, Univ. Federal de Uberlândia (Brazil); P. C. Morais, Univ. de Brasília (Brazil) and Huazhong Univ. of Science and Technology (China);

R. Kashyap, Ecole Polytechnique de Montréal (Canada)

Author Index

iv 


\section{Conference Committee}

Symposium Chair

David L. Andrews, University of East Anglia Norwich (United Kingdom)

Symposium Cochairs

Alexei L. Glebov, OptiGrate Corporation (United States)

Klaus P. Streubel, OSRAM GmbH (Germany)

Program Track Chair

Zameer U. Hasan, Temple University (United States)

Conference Chairs

Richard I. Epstein, The University of New Mexico (United States)

Denis V. Seletskiy, Universität Konstanz (Germany)

Mansoor Sheik-Bahae, The University of New Mexico (United States)

Conference Program Committee

Daniel Bender, Sandia National Laboratories (United States)

Rudolf Binder, College of Optical Sciences, The University of Arizona (United States)

Steven R. Bowman, U.S. Naval Research Laboratory (United States)

Tal Eliezer Carmon, University of Michigan (United States)

Joaquín Fernández, Universidad del País Vasco (Spain)

Zameer UI Hasan, Temple University (United States)

Raman Kashyap, Ecole Polytechnique de Montréal (Canada)

Mauro Tonelli, Università di Pisa (Italy)

Session Chairs

1 Laser Refrigeration in Rare-Earth Doped Systems

Markus P. Hehlen, Los Alamos National Laboratory (United States)

2 Laser Refrigeration in Semiconductor Systems

Martin Weitz, Rheinische Friedrich-Wilhelms-Universität Bonn

(Germany) 
3 Novel Approaches in Laser Cooling

Steven R. Bowman, U.S. Naval Research Laboratory (United States)

4 Advances in Solid-State Laser Refrigeration

Galina A. Nemova, Ecole Polytechnique de Montréal (Canada)

Proc. of SPIE Vol. 8638 863801-6

Downloaded From: https://www.spiedigitallibrary.org/conference-proceedings-of-spie on 26 Apr 2023 Terms of Use: https://www.spiedigitallibrary.org/terms-of-use 